Document downloaded from:

http://hdl.handle.net/10251/66091

This paper must be cited as:

Corma Canós, A.; Gianotti, E.; Díaz Morales, UM.; Velty, A. (2013). Designing bifunctional acid-base mesoporous hybrid catalysts for cascade reactions. Catalysis Science and Technology. 3(10):2677-2688. doi:10.1039/c3cy00269a.

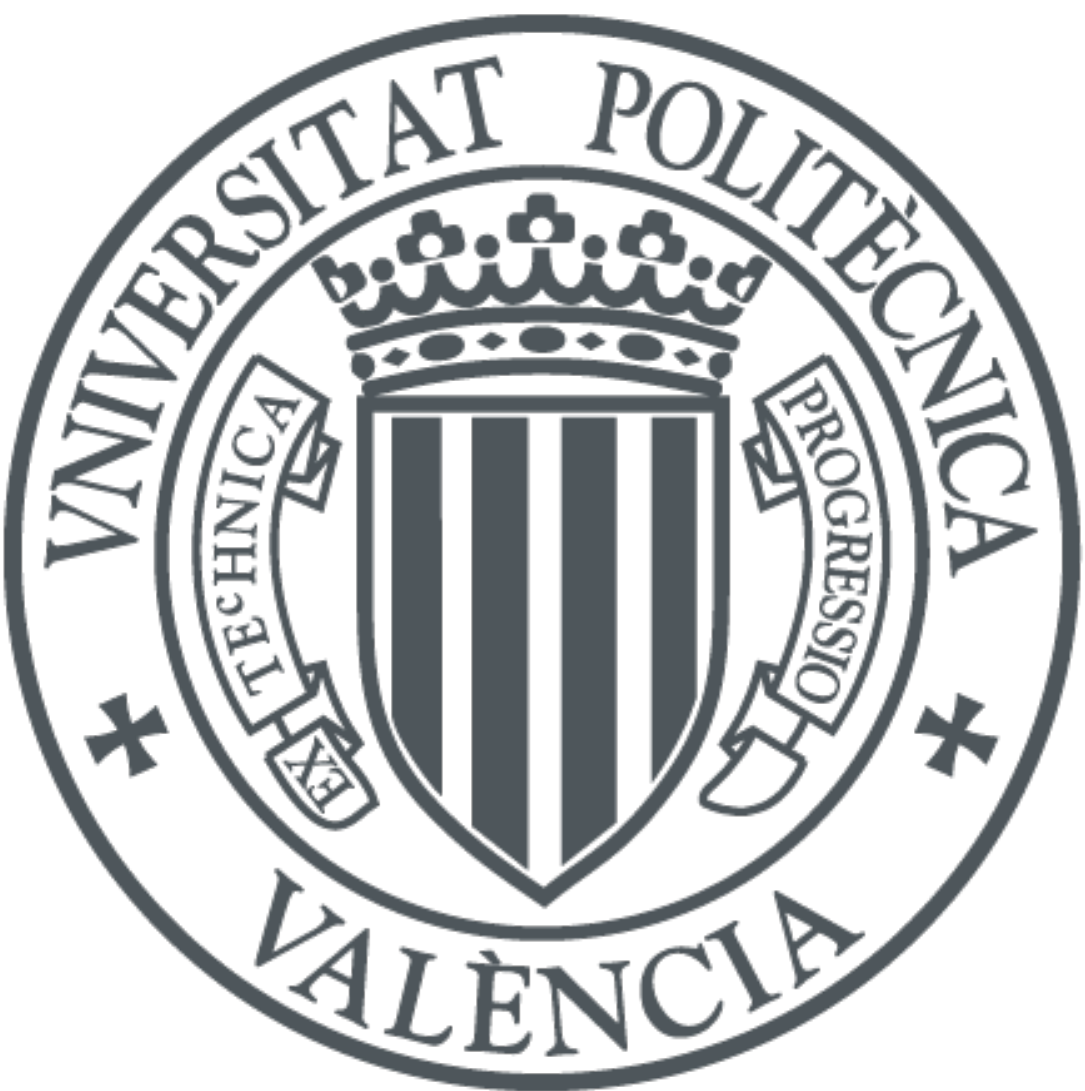

The final publication is available at

http://dx.doi.org/10.1039/c3cy00269a

Copyright Royal Society of Chemistry

Additional Information 


\title{
Designing Bifunctional Acid-Base Mesoporous Hybrid Catalysts for Cascade Reactions
}

\author{
Enrica Gianotti* ${ }^{*}, b$, Urbano Diaz $^{*, a}$, Alexandra Velty ${ }^{a}$, Avelino Corma ${ }^{a}$
}

Designing bifunctional mesoporous hybrid materials, containing concomitantly proton sponges and acid groups, have been prepared following different synthetic routes: co-condensation processes (sol-gel or micellar one-pot route) or post-synthetic grafting of the organic functionalities. 1,8-bis(dimethylamino)naphthalene (DMAN), a proton sponge with high $\mathrm{pK}_{\mathrm{a}}$, was used as organic functional builder base and 3-mercaptopropyltriethoxysilane (MPTES) as pending precursor of sulfonic acids. The bifunctional hybrid materials 10 were extensively characterized and were investigated as heterogeneous catalysts for various one-pot C-C bond-forming cascade reactions such as deacetalization-Knoevenagel condensation or deacetalization-nitroaldol (Henry) reaction.

\section{Introduction}

15 Nature has provided us with efficient catalysts, the enzymes that are able, through sophisticated strategies, achieving complex reactions or driving many biological processes. The highly efficient catalytic abilities of enzymes are due to cooperative interactions between accurately positioned functional groups ${ }_{20}$ present in their active sites. The mimicking of these abilities is one of the challenges in the heterogeneous catalysis and great efforts, in fact, have been focused on the stable immobilization of mutually incompatible functional groups, as in enzymes, that can be able to perform multistep or consecutive reactions. The design

25 of cooperative catalytic systems can be achieved through a wellcontrolled multi-functionalization of inorganic supports such as mesoporous silica. The inorganic porous supports can host different and often incompatible catalytic functionalities separated at suitable molecular distances, such as acid and base 30 groups, providing site isolation inside the inorganic network. The spatial isolation of incompatible active organic groups that cannot coexist in solution is the key to produce bifunctional acid-base heterogeneous hybrid catalysts. Recently, many examples of bifunctionalized mesoporous catalysts have been reported, ${ }^{1}$ in 35 which acid and base functional groups, with different strength, are hosted into the silica matrix such as amines combined together with silanols, ${ }^{2,3}$ thiols, ${ }^{4,5}$ ureas, ${ }^{6,7}$ heteropolyacids ${ }^{8}$ or Lewis and Brønsted acids. ${ }^{9-11}$ In most cases, the catalysts consist in bifunctionalized periodic mesoporous organosilica (PMO), ${ }^{12-14}$ 40 modified SBA-15 ${ }^{15}$ and mesoporous silica nanoparticles (MSNs), ${ }^{7,10,11,16}$ having acid groups within the framework walls and base groups into the channel pores or vice versa. Bifunctional hybrid catalysts with PMO topology are also synthesized using bridged silsesquioxanes in which the organic linkers contain 45 simultaneously acid and base active centers located in the same builder. This approach has been verified through the use of disilane organosilyl precursors which contain ionic liquids as functional building units. ${ }^{17-20}$ Another strategy to produce acidbase bifunctional catalysts focuses on the use of acid sites derived 50 from the inorganic support surfaces such as weak acid silanols in silica $^{21}$ Brønsted acid sites in silica-alumina ${ }^{22}$ or aluminium tetrahedrally coordinated in the framework of the MMW layers in which the base moieties are also incorporated into the inorganic matrix. ${ }^{23}$

55 Among the different synthetic strategies available to covalently incorporate organic functional groups into the silica network, post-synthetic grafting and co-condensation processes are the most suitable. ${ }^{24-26}$ The later approach, also referred as one-pot synthesis, has been the preferred route because of the easier 60 single-pot synthetic protocol and better control of organosilane loading joined to a more homogeneous distribution of active sites; in fact, the grafting method presents several drawbacks such as the partial blockage of the pores and undesired site-site interactions due to the supramolecular association of the silylated 65 organic precursors. In the co-condensation method, the organic molecules can be integrated into the framework of ordered or non-ordered mesoporous silica using bis-silylated precursors. In the synthesis of acid-base functionalized ordered mesoporous silicas (OMS), ${ }^{27}$ the presence of a surfactant, acting as structural 70 directing agent (SDA), is necessary producing a ordered hybrid heterogeneous catalyst, the SDA being removed without altering the properties of the organic moieties incorporated into the framework. To avoid the use of sophisticated and expensive SDAs, a sol-gel procedure catalyzed by $\mathrm{NH}_{4} \mathrm{~F}$ using soft 75 synthesis conditions, room temperature and neutral $\mathrm{pH}$, can be used to synthesize hybrid materials. Through this method, it should be possible to achieve mesoporous hybrid organicinorganic materials that, although they will not have long range order, will have accessible mesopores in a narrow pore size 80 distribution and be thermally stable. ${ }^{28-31}$

The synthesis of multifunctional hybrid materials containing both Brønsted acids and bases is not an easy task, due to the 
incompatible nature of these functional groups. Normally, the base sites are represented by amines that can be easily protected using di-tert-butyl-dicarbonate (BOC). ${ }^{13,32,33}$ This strategy is commonly used for amino group protection during the acid 5 treatment necessary to convert the organosiliceous precursor of acid groups, usually thiols or disulfide moieties, into the corresponding sulfonic acids. Then, a deprotection of the amine groups by thermal treatment is needed to restore the base properties of the hybrid. ${ }^{33}$

10 In this paper, ordered (OMS) and non-ordered bifunctional mesoporous silica materials have been synthesized following grafting and co-condensation procedures, cohabiting in the final materials simultaneously proton sponge and sulfonic groups as organocatalytic units. Remarkably, during the synthesis process, 15 it was avoided the post-synthesis protection and deprotection procedure to preserve the base functionality. Specifically, 1,8bis(dimethylamino)naphthalene (DMAN, scheme 1), a proton sponge, was used as organic builder base and 3mercaptopropyltriethoxysilane (MPTES, scheme 1) as pending 20 precursor of sulfonic acids located along the surface of the mesoporous channels. The organic base may be a part of the solid network if the organosilane contains more than one silicon center, for this reason, DMAN has previously been modified in order to have two terminal reactive silyl groups able to perform co25 condensation with a conventional organosilane (TMOS), through sol-gel or micellar one-pot routes. This method has allowed introducing directly the functionalised DMAN builders into mesoporous silica walls by direct synthesis.

The bifunctional hybrid materials were extensively 30 characterized and were investigated as reusable heterogeneous catalysts for various one-pot $\mathrm{C}-\mathrm{C}$ bond-forming cascade reactions such as deacetalization-Knoevenagel condensation or deacetalization-nitroaldol (Henry) reaction.<smiles>Cc1cccc2cccc(N)c12</smiles>

$$
\text { DMAN }
$$

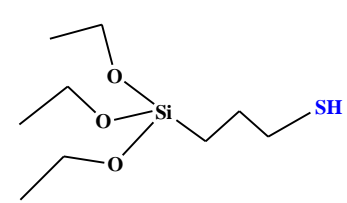

MPTES

Scheme 1 Scheme of 1,8-bis(dimethylamino)naphthalene (DMAN) and 3-mercaptopropyltriethoxysilane (MPTES).

\section{${ }_{45}$ Experimental}

\section{Synthesis of the silylated base precursor}

1,8-bis(dimethylamino)naphthalene (DMAN) was functionalized with terminal silyl-alcoxide reactive groups, ${ }^{34,35}$ (see Fig.1SI for ${ }_{50}$ NMR characterisation of the silyl derived DMAN), obtaining mono and bi-silylated DMAN precursors. In fact, to graft DMAN onto the wall of mesoporous silica, a mono-silylated precursor (DMAN-1Sil) is necessary, whilst two terminal reactive silyl groups (DMAN-2Sil) are needed to integrate the base 55 organocatalysts into the framework of mesoporous material through one-pot synthesis with conventional monosilane precursors (TMOS or TEOS), used as additional silicon sources, through sol-gel or micellar routes.

\section{Synthesis of bifunctional mesoporous hybrids}

${ }_{60} 2.1$ Non-ordered bifunctional mesoporous hybrids

Bifunctional acid-base non-ordered mesoporous hybrids were synthesized using a $\mathrm{NH}_{4} \mathrm{~F}$ sol-gel co-condensation route at low temperature and neutral $\mathrm{pH}$. 3-mercaptopropyltriethoxysilane (MPTES) was used to introduce thiol groups that can be 65 converted in sulfonic acids into the hybrids. Tetramethyl orthosilicate (TMOS), MPTES and disilylated-DMAN (DMAN2Sil) were mixed in methanol at $298 \mathrm{~K}$. After dissolution of precursors, a water solution of $\mathrm{NH}_{4} \mathrm{~F}$ was added under vigorous stirring. The final reaction mixture has the following molar 70 composition:

1-(x+y) TMOS : x DMAN-2Sil : y MPTES : $4 \mathrm{MeOH}: 4 \mathrm{H}_{2} \mathrm{O}$ : $0.00313 \mathrm{NH}_{4} \mathrm{~F}$

Hydrolysis and condensation of the silicon precursors was carried out under vigorous stirring at $298 \mathrm{~K}$ until gelation 75 occurred. Then, the gel was aged at $36^{\circ} \mathrm{C}$ for $24 \mathrm{~h}$ and finally dried at $60^{\circ} \mathrm{C}$ for $24 \mathrm{~h}$. In order to oxidize thiol groups to sulfonic acids, the obtained hybrids were stirred in $30 \% \mathrm{H}_{2} \mathrm{O}_{2}$ solution (30 $\mathrm{ml}$ ) in $\mathrm{N}_{2}$ atmosphere at $30^{\circ} \mathrm{C}$ for $24 \mathrm{~h}$.

With the objective to study the catalytic effect of surface silanol 80 groups, silylated samples with non-ordered organosilica framework were obtained. The bifunctional solids, synthesized following the details above described, were treated with a solution of hexamethyldisilazane (HMDS), as silylating agent, in dry toluene at $120^{\circ} \mathrm{C}$ during $2 \mathrm{~h}$, using a $\mathrm{HMDS} / \mathrm{SiO}_{2}$ ratio of 850.25 . The obtained materials were filtered, washed with dry toluene and finally dried at $60^{\circ} \mathrm{C}$.

\subsection{Ordered bifunctional mesoporous hybrids}

Bifunctional acid-base ordered mesoporous silica (OMS) hybrids 90 were synthesized using a one-pot templated route at room temperature. ${ }^{36}$ Hexadecylamine (HDA) was used as structure directing agent (SDA). 3-mercaptopropyltriethoxysilane (MPTES) was used to introduce thiol groups that can be converted in sulfonic acids into the hybrids after an oxidation 95 process.

Tetraethylorthosilicate (TEOS), MPTES and disilylatedDMAN (DMAN-2Sil) were mixed in ethanol $(80 \mathrm{ml})$ at $298 \mathrm{~K}$ and vigorously stirred for $15 \mathrm{~min}$. The template solution was prepared separately by dissolving $0.05 \mathrm{~mol}$ of HDA in a mixture 100 of $80 \mathrm{ml}$ water and $120 \mathrm{ml}$ ethanol. The TEOS-MPTES-DMAN2Sil mixture was added to the template solution under vigorous stirring at room temperature. The $\mathrm{pH}$ of the synthetic mixture was close to 9.5 . The final reaction mixture has the following molar composition:

105 1-(x+y) TEOS : x DMAN-2Si: y MPTES: 0.25HDA : 21.7 EtOH: $22.2 \mathrm{H}_{2} \mathrm{O}$

The resulting gel mixture was allowed to react at room temperature for $24 \mathrm{~h}$, following which the solid product was obtain by filtration and air dried overnight at $60^{\circ} \mathrm{C}$. Template 110 removal was achieved with ethanol in Soxhlet at $60^{\circ} \mathrm{C}$ for $24 \mathrm{~h}$. In order to convert thiol groups to sulfonic acids, the obtained hybrids were stirred in $30 \% \mathrm{H}_{2} \mathrm{O}_{2}$ solution $(30 \mathrm{ml})$ in $\mathrm{N}_{2}$ atmosphere at $30^{\circ} \mathrm{C}$ for $24 \mathrm{~h}$.

The acronyms of the synthesized bifunctional hybrids are 115 reported in Table 1, together with the DMAN and MPTES loadings. 


\subsection{DMAN grafted on ordered and non-ordered mesoporous silica hybrids}

Mono-silylated DMAN (DMAN-1Sil) was grafted both on ordered and non-ordered materials, which were previously 5 functionalized with pending thiol groups.

Ordered and non-ordered containing MPTES silicas were synthesis following a template route and a $\mathrm{NH}_{4} \mathrm{~F}$ co-condensation route at room temperature, as described above.

The final reaction mixtures have the following molar 10 composition:

1-x TMOS : $x$ MPTES: $4 \mathrm{MeOH}: 4 \mathrm{H}_{2} \mathrm{O}: 0.00313 \mathrm{NH}_{4} \mathrm{~F}$

1-x TEOS : $x$ MPTES: 0.25HDA: $21.7 \mathrm{EtOH}: 22.2 \mathrm{H}_{2} \mathrm{O}$

The resulting gel mixtures were treated as in the case of onepot synthesis. HDA has been removed with Soxhlet extraction in 15 ethanol at $60^{\circ} \mathrm{C}$ for $24 \mathrm{~h}$. Before grafting the organic base (DMAN-1Sil), the solids obtained were stirred with $30 \% \mathrm{H}_{2} \mathrm{O}_{2}$ solution $(30 \mathrm{ml})$ in $\mathrm{N}_{2}$ atmosphere at $30^{\circ} \mathrm{C}$ for $24 \mathrm{~h}$, to oxidize thiol groups to sulfonic acids. The sulfonic functionalized hybrids were pretreated at $100^{\circ} \mathrm{C}$ for $6 \mathrm{~h}$ to remove absorbed water and 20 then cooled at room temperature. Anhydrous toluene $(40 \mathrm{ml})$ and suitable amount of grafting agent (DMAN-1Sil, 1mmol) were added in $\mathrm{N}_{2}$ atmosphere and stirred at $60^{\circ} \mathrm{C}$ for $24 \mathrm{~h}$. Finally, the solids obtained were Soxhlet extracted with methylene chlorideethyl ether (1:1) for 24h to remove the un-reacted DMAN-1Sil 25 molecules. The acronyms of grafted samples with different DMAN and MPTES loadings are reported in Table 1.

Table 1. Acronyms of the bifunctional hybrid materials after the conversion of thiols in sulfonic groups. DMAN and MPTES loadings in 30 the synthesis gel are reported.

\begin{tabular}{|c|c|c|c|c|}
\hline $\begin{array}{l}\text { Sample } \\
\text { Acronyms }\end{array}$ & $\begin{array}{c}\text { DMAN-Sil } \\
\text { loading } \\
\mathrm{x} \\
\end{array}$ & $\begin{array}{c}\text { MPTES } \\
\text { loading } \\
\mathrm{y} \\
\end{array}$ & $\begin{array}{l}\text { Mesoporous } \\
\text { silicas }\end{array}$ & $\begin{array}{l}\text { Synthetic } \\
\text { procedure }\end{array}$ \\
\hline $\mathrm{SO}_{3} \mathrm{H} / \mathrm{SiO}_{2}-5$ & - & 0.05 & Non-ordered & $\begin{array}{c}\mathrm{NH}_{4} \mathrm{~F} \text { route. } \\
\text { One-pot MPTES }\end{array}$ \\
\hline $\begin{array}{l}\text { grDMAN- } \\
\mathrm{SO}_{3} \mathrm{H} / \mathrm{SiO}_{2}-5\end{array}$ & 0.05 & 0.05 & Non-ordered & $\begin{array}{c}\mathrm{NH}_{4} \mathrm{~F} \text { route. } \\
\text { One-pot MPTES. } \\
\text { Grafted DMAN- } \\
\text { 1Sil. }\end{array}$ \\
\hline $\begin{array}{l}\text { DMAN- } \\
\mathrm{SO}_{3} \mathrm{H} / \mathrm{SiO}_{2}-5-5\end{array}$ & 0.05 & 0.05 & Non-ordered & $\begin{array}{c}\mathrm{NH}_{4} \mathrm{~F} \text { route. } \\
\text { One-pot MPTS } \\
\text { and DMAN-2Sil. }\end{array}$ \\
\hline $\mathrm{SO}_{3} \mathrm{H} / \mathrm{OMS}-5$ & - & 0.05 & Ordered & $\begin{array}{l}\text { Micellar route. } \\
\text { One-pot MPTES. }\end{array}$ \\
\hline $\begin{array}{l}\text { grDMAN- } \\
\mathrm{SO}_{3} \mathrm{H} / \mathrm{OMS}-5\end{array}$ & 0.05 & 0.05 & Ordered & $\begin{array}{c}\text { Micellar route. } \\
\text { One-pot MPTES. } \\
\text { Grafted DMAN- } \\
\text { 1Sil. }\end{array}$ \\
\hline $\begin{array}{l}\text { DMAN- } \\
\mathrm{SO}_{3} \mathrm{H} / \mathrm{OMS}-5-5\end{array}$ & 0.05 & 0.05 & Ordered & $\begin{array}{l}\text { Micellar route. } \\
\text { One-pot MPTES } \\
\text { and DMAN-2Sil. }\end{array}$ \\
\hline
\end{tabular}

\section{Characterization of mesoporous hybrids}

${ }_{35}$ All the hybrids were characterized by XRD, $\mathrm{N}_{2}$ adsorption at $77 \mathrm{~K}$, thermogravimetric and elemental analyses, solid state MASNMR $\left({ }^{13} \mathrm{C},{ }^{29} \mathrm{Si}\right)$ and FTIR spectroscopies.

XRD analysis was carried out with a Philips X'PERT diffractometer equipped with a proportional detector and a 40 secondary graphite monochromator. Data were collected stepwise over the $2^{\circ} \leq 2 \theta \leq 10^{\circ}$ angular region, with steps of $0.02^{\circ} 2 \theta$, 20 s/step accumulation time and $\mathrm{Cu} \mathrm{K \alpha}(\lambda=1.54178 \AA)$ radiation.
C, $\mathrm{N}$ and $\mathrm{H}$ contents were determined with a Carlo Erba 1106 elemental analyzer. Thermogravimetric and differential thermal 45 analyses (TGA-DTA) were recorded in $\mathrm{N}_{2}$ stream with a Metler Toledo TGA/SDTA 851E instrument. Volumetric analyses were performed by $\mathrm{N}_{2}$ adsorption isotherms at $77 \mathrm{~K}$ with a Micromeritics ASAP2010. Before the measurements, the samples were outgassed for 12 hours at $100^{\circ} \mathrm{C}$. The BET specific surface $50 \mathrm{area}^{37}$ was calculated from the nitrogen adsorption data in a relative pressure range from 0.04 to 0.2 . The total pore volume ${ }^{38}$ was obtained from the amount of $\mathrm{N}_{2}$ adsorbed at a relative pressure of $\sim 0.99$. External surface area and micropore volume were estimated with the t-plot method in the t range from 3.5 to 5 . 55 The pore diameter and the pore size distribution were obtained following the Barret-Joyner-Halenda (BJH) $\operatorname{method}^{39}$ on the adsorption branch of the isotherms. Transmission electron microscopy (TEM) micrographs were obtained with Philips CM10 with capacity to operate at $100 \mathrm{KV}$.

60 Solid state MAS-NMR spectra were recorded at room temperature under magic angle spinning (MAS) in a Bruker AV400 spectrometer. The single pulse ${ }^{29} \mathrm{Si}$ spectra were acquired at $79.5 \mathrm{MHz}$ with a $7 \mathrm{~mm}$ Bruker BL-7 probe using pulses of $3.5 \mu \mathrm{s}$ corresponding to a flip angle of $3 / 4 \pi$ radians, and a recycle delay ${ }_{65}$ of $240 \mathrm{~s}$ for the ${ }^{13} \mathrm{C}$ cross-polarization (CP) spectra. A $7 \mathrm{~mm}$ Bruker BL-7 probe was used at a sample spinning rate of $5 \mathrm{kHz}$. ${ }^{13} \mathrm{C}$ and ${ }^{29} \mathrm{Si}$ were referred to adamantane and tetramethylsilane, respectively.

FTIR spectra were obtained with a Nicolet 710 spectrometer (4 $70 \mathrm{~cm}^{-1}$ resolution) using a conventional greaseless cell. Wafers of ca. $10 \mathrm{mg} \mathrm{cm}^{-2}$ were outgassed at room temperature, $100^{\circ} \mathrm{C}, 200^{\circ} \mathrm{C}$ and $400^{\circ} \mathrm{C}$ overnight.

\section{One-pot cascade reactions}

75 The bifunctional hybrid catalysts were tested in a one-pot two step reaction that involved an acetal hydrolysis followed by Knoevenagel or nitroaldol condensation. Before catalytic tests, all the catalysts were outgassed at $100^{\circ} \mathrm{C}$ for $12 \mathrm{~h}$ to remove physisorbed water.

80

\subsection{One pot-deacetalization-Knoevenagel reaction}

Malononitrile (MN), ethyl cyanoacetate (ECA) and diethylmalonate (DEM) were used as methylene compounds. A mixture of benzaldehyde dimethylacetal $(5.45 \mathrm{mmol})$, methylene 85 compounds $(5.24 \mathrm{mmol})$ and $\mathrm{H}_{2} \mathrm{O}(30 \mu \mathrm{l})$ was stirred at the desired reaction temperature under $\mathrm{N}_{2}$ atmosphere. Then the bifunctional mesoporous catalyst $(0.05 \mathrm{mmol}$ with $\mathrm{MN}$ and 0.25 mmol of base sites with ECA and DEM) was added and the reaction started. The reaction temperature was $353 \mathrm{~K}$ with $\mathrm{MN}$ 90 and ECA and $383 \mathrm{~K}$ with DEM. In the case of ECA and DEM, toluene was used as solvent.

\subsection{One pot-deacetalization-Henry reaction}

A mixture of benzaldehyde dimethylacetal (5 mmol), $\mathrm{CH}_{3} \mathrm{NO}_{2}$ (20 mmol) and $\mathrm{H}_{2} \mathrm{O}(30 \mu \mathrm{l})$ was stirred at the desired reaction 95 temperature $(363 \mathrm{~K})$ under $\mathrm{N}_{2}$ atmosphere. Then the bifunctional mesoporous catalyst $(0.50 \mathrm{mmol}$ of base sites), was added and the reaction started.

In both types of cascade reactions, the samples were taken periodically, and the evolution of the reaction was followed by ${ }_{100} \mathrm{GC}$ and GC-MS equipped with an Equity-5 column (30 m*0.25 
$\mu \mathrm{m} * 0.25 \mu \mathrm{m})$ and a FID as detector. For catalyst recycling studies, the solid was filtered and thoroughly washed with $\mathrm{CH}_{2} \mathrm{Cl}_{2}$ after each run and then outgassed at $100^{\circ} \mathrm{C}$ for $12 \mathrm{~h}$ to remove the adsorbed species.

5

\section{Results and Discussion}

\section{Synthesis of bifunctional mesoporous hybrids}

Different synthetic methodologies were followed to produce 10 bifunctional mesoporous hybrid materials. Initially, thiols groups, the precursors of sulfonic acids, and DMAN base moieties were simultaneously introduced into the network of ordered (OMS) and non-ordered mesoporous silicas through a one-pot synthesis. More specifically, a micellar self-assembling process, in presence 15 of surfactant molecules (HDA), and a sol-gel route, catalyzed by $\mathrm{NH}_{4} \mathrm{~F}$ as mineralizing agent in the absence of SDA, have been used to prepare ordered and non-ordered mesoporous hybrid materials, respectively, at room temperature. The soft synthetic conditions used allow binding covalently the functionalized 20 organic fragments into the walls of ordered and non-ordered inorganic silicas preserving the base properties of proton sponges in the resultant hybrids. In the case of ordered mesoporous silica synthesis, due to the instability of the strong base DMAN molecules in acid conditions, neutral long chains amine (HDA) 25 has been choose as SDA for micellar self-assembly route, instead of triblock copolymers, such as P123, that requires strong acid conditions during the synthesis. ${ }^{36}$ In addition, the extraction of the SDA molecules in ordered mesoporous hybrid materials has been carried out using neutral ethanol solutions to preserve the 30 DMAN moieties. In scheme 2, a representation of the two processes used to synthesize the bifunctional hybrids are reported, the last step for both processes being the oxidation of the thiol groups in strong sulfonic acid sites by using a $\mathrm{H}_{2} \mathrm{O}_{2}$ aqueous solution, without the use of strong acid solution that also 35 would negatively affect the base properties of DMAN.

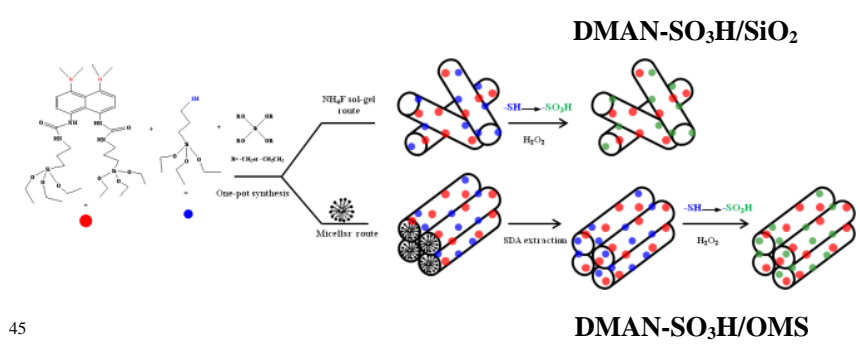

Scheme 2- One-pot synthesis of bifunctional mesoporous hybrids

Additionally, DMAN base molecules were grafted through post-synthesis treatments, pending from the walls of ordered and 50 non-ordered mesoporous silicas channels, after the transformation of thiols into sulfonic acids, as reported in scheme 3. In this case, more post-synthesis steps (anchoring and oxidation processes) are involved in the preparation of the bifunctional hybrid mesoporous materials.

55

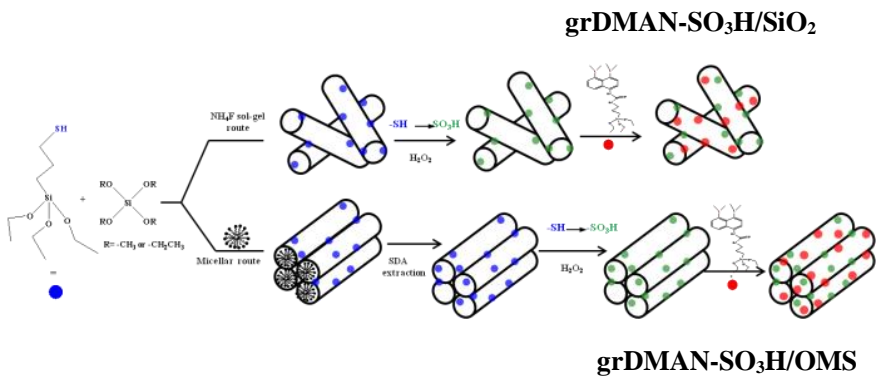

Scheme 3- DMAN grafting on mesoporous silicas containıng suıronic acids.

70

\section{Characterization of bifunctional mesoporous hybrids}

The ordered mesoporous hybrid silicas (OMS) were characterized by XRD diffraction analysis (Fig. 1). The pattern of the hybrids 75 mainly exhibited the (100) reflection peak at low diffraction angles which is typical of M41S mesoporous materials exhibiting short range hexagonal ordering. ${ }^{36,40}$ In the as-synthesized $\mathrm{SO}_{3} \mathrm{H} / \mathrm{OMS}-5$ (curve a) and surfactant-extracted $\mathrm{SO}_{3} \mathrm{H} / \mathrm{OMS}-5$ (curve b) are also visible the (110) peak due to the long-range 80 order in the silica framework. Upon extraction of the HDA (curve b), the $d_{100}$ peak increases in intensity due to a better ordering of the inorganic framework. The hexagonal order is maintained also after the post-synthetic grafting procedure (curve c) and after the oxidation of the thiol groups (curve d) in the bifunctional ordered ${ }_{85}$ OMS prepared with one-pot synthesis. The high intensity of the (100) peak confirms the homogeneous structural order of the hybrid materials prepared using self-assembly micellar route.

However, the reduced intensity of (110) and (200) diffraction peaks after the post-synthetic treatments (curve $\mathrm{c}$ and $\mathrm{d}$ ) ${ }_{90}$ evidenced a loss of the long range order in the final materials. Obviously, the non-ordered hybrid mesoporous materials, obtained by sol-gel process, do not show low-angle diffraction peak typical of M41S systems.

95

100

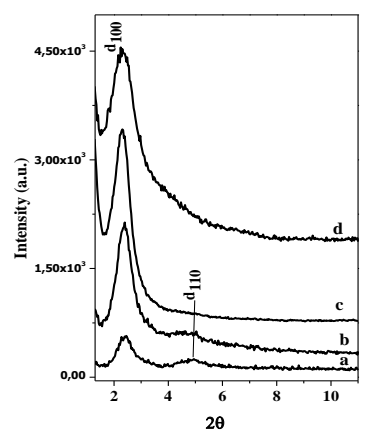

Fig. 1 - Powder XRD diffraction patterns of as-synthesized $\mathrm{SO}_{3} \mathrm{H} / \mathrm{OMS}-5$ (curve a), surfactant-extracted $\mathrm{SO}_{3} \mathrm{H} / \mathrm{OMS}-5$ (curve b), grDMAN$110 \mathrm{SO}_{3} \mathrm{H} / \mathrm{OMS}-5$ (curve c) and surfactant-extracted bifunctional DMAN$\mathrm{SO}_{3} \mathrm{H} / \mathrm{OMS}-5-5$ (curve d) after the oxidation of thiol groups.

The ordered bifunctional OMS and the non-ordered bifunctional silicas show different morphology as evidenced by the TEM 115 micrographs in Fig. 2. In particular, the ordered materials are formed by larger particles (a), whilst smaller organosilica particles are visible in the micrograph of the bifunctional nonordered silica (b). In both hybrid materials, it is possible to 
observe the presence of mesopores, being appreciated an important inter-particle mesoporous contribution in the hybrid obtained by $\mathrm{NH}_{4} \mathrm{~F}$ sol-gel route. The homogeneous mesoporous distribution is clearly appreciated in the hybrid solids synthesized 5 by template assisted methodology.
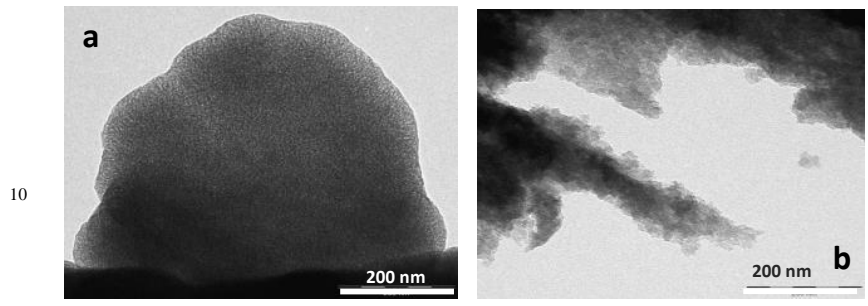

Fig. 2 - TEM micrographs: (a) DMAN-SO ${ }_{3} \mathrm{H} / \mathrm{OMS}-5-5$ and (b) DMAN$15 \mathrm{SO}_{3} \mathrm{H} / \mathrm{SiO}_{2}-5-5$.

The presence of the organic moieties in the synthesized hybrid materials was evidenced by means of elemental analysis. In Table 2, the $\mathrm{C}, \mathrm{H}, \mathrm{N}$ content and the calculated percentage in weight of 20 the organic species present into the bifunctional hybrid materials are reported. The organic content of the OMS hybrids is higher with respect to the one of the hybrids prepared with the sol-gel process, moreover in both the grafted-DMAN hybrids the organic content is higher respect the hybrids produced with one-pot 25 synthesis.

Table 2 - Organic content in the mesoporous bifunctional hybrids estimated by Elemental Analysis.

\begin{tabular}{lccccc}
\hline Catalysts & $\mathrm{N} \%$ & $\mathrm{C} \%$ & $\mathrm{H} \%$ & $\mathrm{~S} \%$ & $\begin{array}{c}\text { Organic } \\
\text { content } \\
(\mathrm{EA}) / \%\end{array}$ \\
\hline $\mathrm{SO}_{3} \mathrm{H} / \mathrm{SiO}_{2}-5$ & - & 4.4 & 2.2 & 1.5 & 8.1 \\
grDMAN-SO$_{3} \mathrm{H} / \mathrm{SiO}_{2}-5$ & 2.1 & 12.8 & 2.4 & 1.6 & 18.9 \\
$\mathrm{DMAN}_{-} \mathrm{SO}_{3} \mathrm{H} / \mathrm{SiO}_{2}-5-5$ & 1.4 & 9.2 & 2.4 & 1.5 & 14.5 \\
$\mathrm{SO}_{3} \mathrm{H} / \mathrm{OMS}-5$ & 0.2 & 5.2 & 2.0 & 1.4 & 8.8 \\
grDMAN-SO & & & & & \\
DMAMS-5 & 2.7 & 15.4 & 2.7 & 1.6 & 22.4 \\
\hline
\end{tabular}

30

Thermogravimetric analysis was performed in order to gain insight on the organic content, on the thermal stability of the inserted DMAN and sulfonic groups and on the hydrophobic/hydrophilic character of the hybrid materials. The 35 weight loss (TGA) and their respective derivates (DTA) for the one-pot non-ordered DMAN-SO $\mathrm{S}_{3} \mathrm{H} / \mathrm{SiO}_{2}-5-5$ and ordered DMAN-SO 3 H/OMS-5-5 are reported in Fig. 3 Section A. The first weight loss for the bifunctional hybrids is observed at around $80-150^{\circ} \mathrm{C}$ and can be associated to the removal of physisorbed 40 water (I). The DTA curves reveal that the non-ordered DMAN$\mathrm{SO}_{3} \mathrm{H} / \mathrm{SiO}_{2}-5-5$ is more hydrophilic than ordered DMAN$\mathrm{SO}_{3} \mathrm{H} / \mathrm{OMS}-5-5$, i.e., has a larger amount of adsorbed water. At higher temperatures, flat weight loss profiles changed into a rapidly declining profile corresponding to the decomposition of 45 the organic base (DMAN) and sulfonic acid groups. In particular, the DTA curves reveal that DMAN decomposes between 300$430^{\circ} \mathrm{C}$ (II) and sulfonic acids at ca. $500-550^{\circ} \mathrm{C}$ (III). ${ }^{41,42} \mathrm{In}$ fact, the DTA curves of $\mathrm{SO}_{3} \mathrm{H} / \mathrm{SiO}_{2}-5$ and $\mathrm{SO}_{3} \mathrm{H} / \mathrm{OMS}-5$ (Section $\mathrm{C}$, curves $\mathrm{c}$ and $\mathrm{d}$ ) have evidenced that the alkyl-sulfonic acid groups ${ }_{50}$ decompose at ca. $500-550^{\circ} \mathrm{C}$ (III). The presence of a weight loss at this high temperature in the bifunctionalized hybrids confirms the complete oxidation of thiols into sulfonic groups. Moreover, in the case of $\mathrm{SO}_{3} \mathrm{H} / \mathrm{OMS}-5$ (Section $\mathrm{C}$, curve d), a weight loss at around $350^{\circ} \mathrm{C}$ is also visible, that can be associated with the 55 decomposition of the residual of HDA molecules that were not completely removed after the surfactant extraction. The DTA curves of grafted-DMAN hybrids (Section B, curves $\mathrm{c}$ and $\mathrm{d}$ ) showed a minor weight loss at around $80-150^{\circ}$ suggesting, a lower amount of physisorbed water with respect the one-pot 60 bifunctional hybrids. In fact, in the grafted hybrids the concentration of silanols should be lower due to the fact that the $\mathrm{Si}-\mathrm{OH}$ groups are the locus on which the grafting of the base DMAN occurs. The second weight loss at around $300-430^{\circ} \mathrm{C}$ is due to the organic DMAN base and the third peak at ca. 500${ }_{65} 550^{\circ} \mathrm{C}$, due to the decomposition of alkyl-sulfonic acid groups, confirms that the acid properties are not altered by the postsynthetic grafting of the organic base. The organic content, calculated from the weight loss in the $150-430^{\circ} \mathrm{C}$ range, due to the decomposition of the DMAN base, and in the $430-900^{\circ} \mathrm{C}$ 70 range, where sulfonic groups decomposed, is in agreement with the results obtained by elemental analysis (Table 2). Moreover, the hybrids prepared with sol-gel synthesis that present a lower organic content, have a higher degree of hydrophilicity.

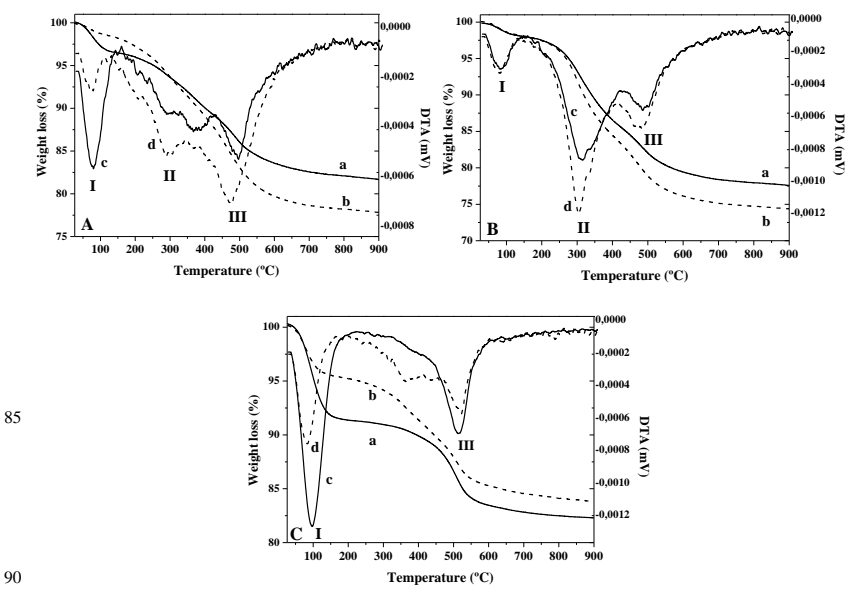

Fig. 3 - Section A: TGA and DTA curves of DMAN-SO ${ }_{3} \mathrm{H} / \mathrm{SiO}_{2}-5-5$ (a and c) and DMAN-SO 3 H/OMS-5-5 (b and d). Section B: TGA and DTA curves of grDMAN-SO ${ }_{3} \mathrm{H} / \mathrm{SiO}_{2}-5$ (a and c) and grDMAN-SO ${ }_{3} \mathrm{H} / \mathrm{OMS}-5$ 95 (b and d). Section C: TGA and DTA curves of $\mathrm{SO}_{3} \mathrm{H} / \mathrm{SiO}_{2}-5$ (a and c) and $\mathrm{SO}_{3} \mathrm{H} / \mathrm{OMS}-5$ (b and d).

Table 3 -Weight loss (\%) due to organic content calculated from TGA analysis.

\begin{tabular}{lccccc}
\hline Catalysts & $\begin{array}{c}\Delta \mathrm{wt} \% \\
\text { due to } \\
\mathrm{H}_{2} \mathrm{O}^{\mathrm{a}} \\
(\mathrm{I})\end{array}$ & $\begin{array}{c}\Delta \mathrm{wt} \% \\
\text { due to } \\
\mathrm{DMAN}^{\mathrm{b}}\end{array}$ & $\begin{array}{r}\Delta \mathrm{wt} \% \\
\text { due to } \\
-\mathrm{SO}_{3} \mathrm{H}^{\mathrm{c}} \\
(\mathrm{III})\end{array}$ & $\begin{array}{r}\Delta \mathrm{wt} \% \\
\text { due to } \\
\text { organic } \\
\text { content }\end{array}$ & $\begin{array}{r}\text { Organic } \\
\text { content } \\
(\mathrm{EA}) / \%\end{array}$ \\
\hline $\mathrm{SO}_{3} \mathrm{H} / \mathrm{SiO}_{2}-5$ & 8.2 & - & 9.0 & 9.0 & 8.1 \\
grDMAN-SO$_{3} \mathrm{H}_{2} \mathrm{SiO}_{2}-5$ & 2 & 13 & 6.6 & 19.6 & 18.9 \\
$\mathrm{DMAN}-\mathrm{SO}_{3} \mathrm{H} / \mathrm{SiO}_{2}-5-5$ & 3.6 & 8.9 & 5.2 & 14.1 & 14.5 \\
$\mathrm{SO}_{3} \mathrm{H} / \mathrm{OMS}-5$ & 4.4 & - & 9.8 & 9.8 & 8.8 \\
grDMAN-SO & 2 & 15 & 7.9 & 22.9 & 22.4 \\
\hline
\end{tabular}




\begin{tabular}{llllll}
\hline DMAN-SO & & & & & \\
\hline
\end{tabular}

a physisorbed $\mathrm{H}_{2} \mathrm{O}$ calculated from $25^{\circ} \mathrm{C}$ to $150^{\circ} \mathrm{C}$; ${ }^{\text {b calculated from } 150^{\circ} \mathrm{C}}$ to $430^{\circ} \mathrm{C}$; ${ }^{c}$ calculated from $430^{\circ} \mathrm{C}$ to $900^{\circ} \mathrm{C}$.

The chemical nature of the organic moieties present into the 5 ordered and non-ordered hybrid mesoporous silicas has been studied by ${ }^{13} \mathrm{C}-\mathrm{CP}$ MAS NMR technique (Fig. 4). The contribution of the DMAN, the organic base, and the MPTES, the precursor of pending sulfonic groups, was evidenced and also the oxidation of thiols into sulfonic groups upon the treatment with ${ }_{10} \mathrm{H}_{2} \mathrm{O}_{2}$ was confirmed. Specifically, the ${ }^{13} \mathrm{C} \mathrm{CP} / \mathrm{MAS}$ NMR spectra of the bifunctional hybrids (Fig. 4, curves b-e) present the typical signals of DMAN confirming the integrity of the organic base after the synthesis process. In fact, in the range between 150-110 ppm, weak signals, due to naphthalene groups, are present, while 15 the peaks due to methyl groups belonging to $\mathrm{N}\left(\mathrm{CH}_{3}\right)_{2}$ are visible at $40-45$ ppm. ${ }^{43,44}$ In addition, the peak assigned to $\mathrm{C}=\mathrm{O}$ groups (158 ppm), and the signals due to C1 (61 ppm), C2 (22 ppm) and $\mathrm{C} 3(10 \mathrm{ppm})$ of the $-\mathrm{CH}_{2}$ groups belonging to the terminal silyl fragments of the functionalized DMAN are also present (see the 20 inset in Fig. 4 for the labels of C atoms). ${ }^{45}$ The presence of these signals also confirms that the DMAN molecules were successfully functionalized. Concerning MPTES, in the spectrum of DMAN-MPTES/SiO ${ }_{2}-5-5$ hybrid (curve b), a signal at $27 \mathrm{ppm}$, typical of $\mathrm{C} 1$ and $\mathrm{C} 2$ carbons adjacent to the $-\mathrm{SH}$ groups is 25 evident, confirming the presence of mercaptopropyl groups, which are not present in the samples synthesized with only protonic sponge silyl-precursors (curve a); whilst the peak due to $\mathrm{C} 3$, that should appear at $11 \mathrm{ppm}$, is overlapped to the strong signal at $10 \mathrm{ppm}$ due to the functionalized DMAN. Upon the 30 oxidation with $\mathrm{H}_{2} \mathrm{O}_{2}$, necessary to convert thiols to suphonic groups, the peak at $27 \mathrm{ppm}$ disappeared and contemporarily new signals at $54 \mathrm{ppm}$, due to $\mathrm{C} 1$, and at $18 \mathrm{ppm}$ due to $\mathrm{C} 2$ adjacent to the $-\mathrm{SO}_{3} \mathrm{H}$ groups, appeared (curves c-e), suggesting a complete oxidation of thiols in $-\mathrm{SO}_{3} \mathrm{H}$ groups. ${ }^{41,42,46,47}$ The signal due to 35 sulfonic acids is also present after the grafting of the DMAN organic base onto the mesoporous silica (curve e) and this confirms that the post-synthetic procedure used to graft the organic base does not affect the strong acid sites.

40

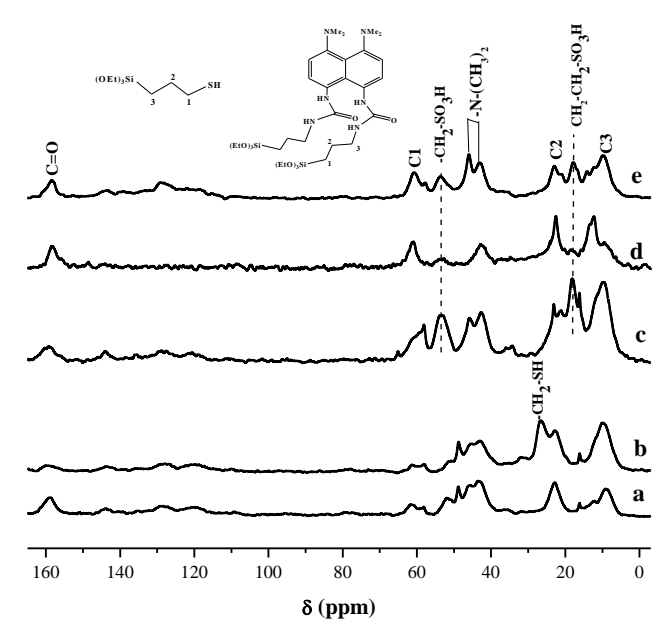

Fig. 4 - ${ }^{13} \mathrm{C}-\mathrm{CP}$ MAS NMR of $\mathrm{DMAN} \mathrm{SiO}_{2}-5$ (curve a), DMANMPTES/SiO $2-5-5$ (curve b), DMAN-SO ${ }_{3} \mathrm{H} / \mathrm{SiO}_{2}-5-5$ (curve c), DMAN$\mathrm{SO}_{3} \mathrm{H} / \mathrm{OMS}-5-5$ (curve d) and grDMAN-SO ${ }_{3} \mathrm{H} / \mathrm{SiO}_{2}-5$ (curve e).
Additionally, ${ }^{29}$ Si MAS NMR spectra confirm that the DMAN ${ }_{60}$ fragments and MPTES are not only intact after the synthesis of the bifunctional hybrids but are also incorporated covalently into the ordered and non-ordered porous network bounded to inorganic silica units. In fact, the ${ }^{29} \mathrm{Si}$ MAS NMR spectra of the bifunctional hybrids (Fig.5 curves b and c) exhibit bands from ${ }_{65} 50 \mathrm{ppm}$ to $-80 \mathrm{ppm}$ assigned to $\mathrm{T}$-type silicon $\left(\mathrm{T}^{3}, \mathrm{~T}^{2}\right.$ and $\left.\mathrm{T}^{\mathrm{t}}\right)$ species having a $\mathrm{Si}-\mathrm{C}$ covalent bond, these signals being not present in the spectrum of siliceous material (curve a) synthesized for comparison, and then confirming that the hydrolysis and polycondensation of silylated-DMAN and MPTES occurs through 70 reactive alkoxy terminal groups of the silylated moieties. In the spectrum of DMAN-SO $\mathrm{S}_{3} \mathrm{H} / \mathrm{SiO}_{2}-5-5$ (curve b), it is possible to identify the T-bands corresponding to the $\mathrm{T}^{4}$ ( $\left.\mathrm{SiC}(\mathrm{OH})_{2}(\mathrm{OSi})\right), \mathrm{T}^{2}$ $\left(\mathrm{SiC}(\mathrm{OH})(\mathrm{OSi})_{2}\right)$ and $\mathrm{T}^{3}\left(\mathrm{SiC}(\mathrm{OSi})_{3}\right)$, whilst in the DMAN$\mathrm{SO}_{3} \mathrm{H} / \mathrm{OMS}-5-5$ spectrum (curve c), only the band due to $\mathrm{T}^{3}$ is 75 visible, showing that more complete hydrolysis and polycondensation of alkoxide terminal groups, present in the silane precursors, occur during the one-pot micellar route. In addition, three peaks at $-92,-100$ and $-110 \mathrm{ppm}$ are also present, due to $\mathrm{Q}^{2}$ $\left(\mathrm{Si}(\mathrm{OH})_{2}(\mathrm{OSi})_{2}\right), \mathrm{Q}^{3}\left(\mathrm{Si}(\mathrm{OH})(\mathrm{OSi})_{3}\right)$ and $\mathrm{Q}^{4}\left(\mathrm{Si}(\mathrm{OSi})_{4}\right)$ silicon 80 units respectively, ${ }^{48}$ which are typical of highly siliceous conventional mesoporous materials, associated to tetrahedrally coordinated silicon atoms conforming the solid network.

The incorporation of the disilylated DMAN into the framework of non-ordered and ordered mesoporous silica is also ${ }_{85}$ confirmed by the comparison of ${ }^{29} \mathrm{Si}$ NMR spectra of the hybrids with the pure disilylated DMAN (see inset of Fig.5). The DMAN2 Sil exhibits one peak centered at $-45 \mathrm{ppm}$ typical of $\mathrm{Si}-\mathrm{C}$ bonds. When the DMAN-2Sil builders are finally inserted into the silica framework, the signal due to silicon atoms bounded to carbon 90 units shifted in the range -50 to $-80 \mathrm{ppm}$, supporting the covalent incorporation of the disilylated organic species into the silica framework.

The integration of $\mathrm{T}$ and $\mathrm{Q}$ peaks in the ${ }^{29} \mathrm{Si} \mathrm{BD} / \mathrm{MAS}$ NMR spectra was performed to calculate the $\mathrm{T} /(\mathrm{Q}+\mathrm{T})$ ratio and to 95 evaluate the number of functionalized silicon atoms in the hybrids (Table 4). The $\mathrm{Si}_{\text {func }} / \mathrm{Si}_{\text {tot }}$ ratio evidences that DMAN$\mathrm{SO}_{3} \mathrm{H} / \mathrm{SiO}_{2}-5-5$ has a higher amount of $\mathrm{Si}$ atoms functionalized by organic linkers ( 11\%) than DMAN-SO 3 H/OMS-5-5 ( 7.7\%).

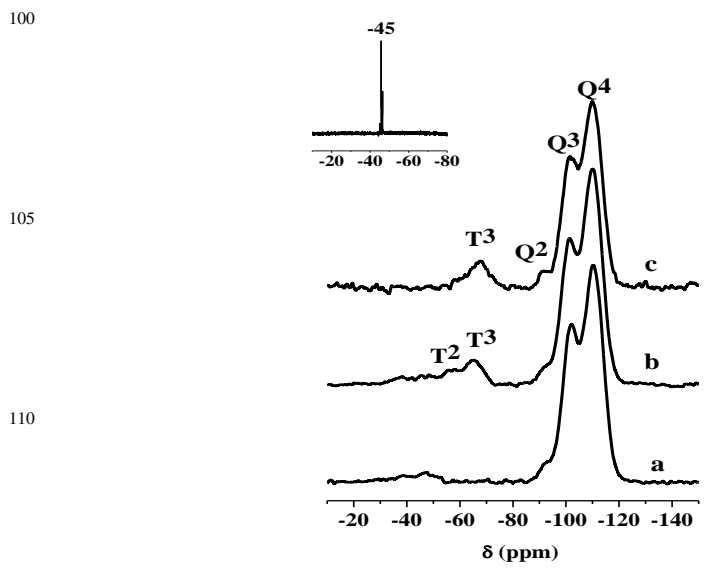

115

Fig. 5 - ${ }^{29} \mathrm{Si}-\mathrm{BD}$ MAS NMR of pure $\mathrm{SiO}_{2}$ (curve a), DMAN-SO $3 \mathrm{H} / \mathrm{SiO}_{2}-$ 
5-5 (curve b) and DMAN-SO 3 H/OMS-5-5 (curve c). In the inset, the ${ }^{29} \mathrm{Si}$ NMR spectrum of pure DMAN-2Sil is reported.

Table 4 - Functionalized silicon atoms in the hybrids.

\begin{tabular}{|c|c|c|}
\hline Samples & $\mathrm{Si}_{\text {fund }} / \mathrm{Si}_{\mathrm{tot}}(\mathrm{NMR})$ & $\mathrm{T}_{1}+\mathrm{T}_{2} / \mathrm{T}$ \\
\hline DMAN-SO ${ }_{3} \mathrm{H} / \mathrm{SiO}_{2}-5-5$ & 0.11 & 0.57 \\
\hline DMAN-SO ${ }_{3} \mathrm{H} / \mathrm{OMS}-5-5$ & 0.077 & 0 \\
\hline
\end{tabular}

5

FTIR spectroscopy confirms unambiguously both the presence and integrity of organic DMAN and MPTES builders in the network of the bifunctional hybrid materials and the complete transformation of thiols into sulfonic groups. In fact, the weak 10 band at $2570 \mathrm{~cm}^{-1}$ present in the spectrum of DMANMPTES/SiO $2-5-5$ (Fig.6, curve a), due to the S-H stretching mode of thiol groups, disappeared upon the treatment with $\mathrm{H}_{2} \mathrm{O}_{2}$ and a new the band at $1370 \mathrm{~cm}^{-1}$ due to the asymmetric stretching of $\mathrm{S}=\mathrm{O}$ is formed (Fig. 6, curve b), this signal is also present in the 15 spectrum of $\mathrm{SO}_{3} \mathrm{H} / \mathrm{SiO}_{2}-5$ system (curve c). ${ }^{41,42,49}$ In addition, at higher frequencies, the bands due to the $\mathrm{C}-\mathrm{H}$ stretching of $-\mathrm{CH}_{2}$ (2930 and $2855 \mathrm{~cm}^{-1}$ ) groups are present both in the spectra of bifunctional hybrids (curves a and b) and $\mathrm{SO}_{3} \mathrm{H}-\mathrm{SiO}_{2}$ (curve c). At lower wavenumber, the bifunctional hybrids (Fig. 6, curves a 20 and b), show a bands at $1530 \mathrm{~cm}^{-1}$, associated to the stretching mode of the aromatic $\mathrm{C}=\mathrm{C}$, and a band at $1690 \mathrm{~cm}^{-1}$, due to the stretching mode of the carbonyl group present in the functionalized DMAN, these signals confirm the presence and the integrity of the proton sponge moieties into the bifunctional 25 hybrids.

30

35

40

Fig. 6 - FTIR spectra of DMAN-MPTES/SiO ${ }_{2}-5-5$ (curve a), DMAN$\mathrm{SO}_{3} \mathrm{H} / \mathrm{SiO}_{2}-5-5$ (curve b) and $\mathrm{SO}_{3} \mathrm{H} / \mathrm{SiO}_{2}-5$ (curve c) upon outgassing at $100^{\circ} \mathrm{C}$.

45

\section{Textural properties of the hybrid materials}

The textural properties of the hybrids, measured by $\mathrm{N}_{2}$ adsorption at $77 \mathrm{~K}$, are reported in Table 5 . In general, the BET specific 50 surface area (SSA) of the non-ordered $\mathrm{SiO}_{2}$ hybrids is lower than the ordered-OMS materials. However, in the ordered hybrid materials, important differences are observed when DMAN moieties are introduced by co-condensation or post-synthetic grafting routes. When DMAN bridged silsesquioxane and

55 MPTES are incorporated one-pot during the synthesis, the isotherm obtained exhibits a shape more similar to the non- ordered silica with inflexion point close to $\mathrm{p} / \mathrm{p}^{\circ} 0.5$, showing a reduction in the homogeneous porosity and in the SSA when the two silane precursors are simultaneously incorporated into the ${ }_{60}$ framework. This behavior is probably due to the difficulty in assembling the two types of silane precursors in a highly regular mesoporous structure during the one-pot synthetic route. On the contrary, if the DMAN precursors are grafted onto the mesopores of OMS or in absence of them, the hybrid materials show type IV 65 isotherms, clearly representative of standard M41S materials, with inflexion point at ca. $\mathrm{p} / \mathrm{p}^{\mathrm{o}} 0.3$. The non-ordered hybrid materials synthesized through fluoride-catalyzed sol-gel route, exhibit a more reduced porosity compared with the ordered materials, associated to tortuous and irregular mesoporous 70 channels, in fact the isotherms present a reduced slope and inflexion points at higher relative pressure $\left(\mathrm{p} / \mathrm{p}^{\mathrm{o}} \sim 0.5\right)$. It is important to remark that in all cases, the SSAs and pore volumes obtained are in the mesoporous range, being very small the microporous contribution (Table 4). The pore distribution of the 75 hybrid samples (Fig.7B) is narrow and the mean pore diameters are centered at 28-30 ̊.

Table 5 - Textural properties of the bifunctional mesoporous hybrid materials.

80

\begin{tabular}{|c|c|c|c|c|}
\hline Catalysts & $\begin{array}{l}\mathrm{SSA}_{\mathrm{BET}} \\
\left(\mathrm{m}^{2} / \mathrm{g}\right) \\
\end{array}$ & $\begin{array}{c}\text { External SA } \\
\left(\mathrm{m}^{2} / \mathrm{g}\right)\end{array}$ & $\begin{array}{c}\text { Pore size } \\
\AA \\
\end{array}$ & $\begin{array}{c}\text { Pore volume } \\
\mathrm{cm}^{3} / \mathrm{g} \\
\end{array}$ \\
\hline $\mathrm{SO}_{3} \mathrm{H} / \mathrm{SiO}_{2}-5$ & 599 & 422 & 27 & 0.22 \\
\hline grDMAN-SO ${ }_{3} \mathrm{H} / \mathrm{SiO}_{2}-5$ & 436 & 393 & 26 & 0.21 \\
\hline DMAN-SO ${ }_{3} \mathrm{H} / \mathrm{SiO}_{2}-5-5$ & 481 & 472 & 31 & 0.25 \\
\hline $\mathrm{SO}_{3} \mathrm{H} / \mathrm{OMS}-5$ & 930 & 673 & 28 & 0.22 \\
\hline grDMAN-SO ${ }_{3} \mathrm{H} / \mathrm{OMS}-5$ & 793 & 719 & 27 & 0.19 \\
\hline DMAN-SO ${ }_{3} \mathrm{H} / \mathrm{OMS}-5-5$ & 590 & 542 & 28 & 0.19 \\
\hline
\end{tabular}
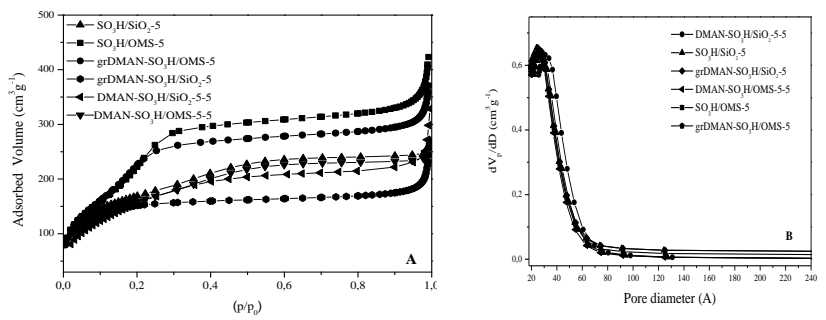

Fig. 7 - Section A: $\mathrm{N}_{2}$ adsorption isotherms and Section B: Pore size distribution, calculated by BJH method, of the hybrid materials.

\section{${ }_{95}$ 4. Catalytic activity in one-pot cascade reaction}

One-pot-two step processes that involved an acid-catalyzed acetal hydrolysis followed by a base-catalyzed Knoevenagel or nitroaldol (Henry) reactions were performed to investigate how the acid and base functionalities of the organic-inorganic hybrids 100 cooperate synergistically. The first step is the deacetalisation of the benzaldehyde dimethylacetal to benzaldehyde, that, in the second step, reacts with metylene compounds (Knoevenagel condensation, scheme 4) or nitromethane (Henry reaction, scheme 5) to give the final product.

105 The condensation of carbonyl compounds (Knoevenagel condensation) and the condensation of nitroalkanes with carbonyl 
compounds (Henry reaction) are well-established and widely used in organic synthesis to produce important intermediates and end products for perfumes, pharmaceutical and polymers. ${ }^{49-54}$ However, in the case of Henry reaction, the selective formation of 5 a nitroalkene (product 4 in scheme 5), using conventional strong bases is difficult to achieve since the conjugate addition of the nitroalkane to the $\mathrm{C}-\mathrm{C}$ double bond of the nitrolkene gives bisnitro compounds in a side reaction, therefore the synthesis of nitroalkenes often proceeds in poor yields due to their 10 dimerisation or polymerization. ${ }^{55-57}$

4.1 One pot-deacetalization-Knoevenagel reaction: The Knoevenagel condensation is a facile and versatile route to the formation of carbon-carbon bonds. ${ }^{58}$ It is a key reaction to synthesize important class of intermediates in the cosmetic and 15 pharmaceutical industries ${ }^{59}$ due to their properties as enzyme inhibitors, antitumor, anti-inflammatory, and antibacterial agents. $^{60-64}$ Besides the importance of the Knoevenagel condensation as a synthetic organic method, another relevant characteristic of this reaction is its ability to measure the number 20 and the relative strength of base active sites, by reacting a series of methylenic compounds with different $\mathrm{pK}_{\mathrm{a}}$ values. ${ }^{65}$ Thus, the Knoevenagel condensation between benzaldehyde and substrates with different $\mathrm{pK}_{\mathrm{a}}$ values (with distinct activated methylenic groups), such as malononitrile ( $\mathrm{MN}, 3 \mathrm{a}) \quad\left(\mathrm{pK}_{\mathrm{a}} \approx 7\right)$, ethyl 25 cyanoacetate $(\mathrm{ECA}, 3 \mathrm{~b})\left(\mathrm{pK}_{\mathrm{a}} \approx 9\right)$, ethyl acetoacetate $\left(\mathrm{pK}_{\mathrm{a}} \approx 11\right)$ and diethyl malonate (DEM, 3c) $\left(\mathrm{pK}_{\mathrm{a}} \approx 13\right)$ are extensively performed in order to characterize base catalysts.

Here, we compared the catalytic performance of acid-base catalysts synthesized following different strategies to carry out 30 one-pot cascade reaction: acid-catalyzed first step, benzaldehyde dimethyl acetal hydrolysis and, base-catalyzed second step, Knoevenagel reaction with different $\mathrm{pK}_{\mathrm{a}}$ substrates (Scheme 4).
40<smiles>COC(OC)c1ccccc1</smiles>

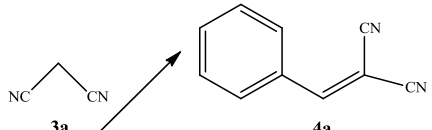

$4 a$

75

80

performed since $97 \%$ yield of the final product with $100 \%$ selectivity was achieved after $6 \mathrm{~h}$. Similar yields $(\geq 95 \%)$ of the final product with $100 \%$ selectivity were observed for the other one-pot and grafted-DMAN ordered and non-ordered bifunctional hybrid catalysts (Table 6) at the same reaction time. A blank ${ }_{65}$ experiment without the heterogeneous catalyst was also performed (entry 5, Table 6), and the results show that the cascade reaction does not occur in the absence of the hybrid catalyst. When $\mathrm{MN}$ is used as methylene compound, all the catalysts showed good and similar catalytic performances in the 70 cascade reaction after $6 \mathrm{~h}$ and no dependence of the synthesis procedure can be evidenced.

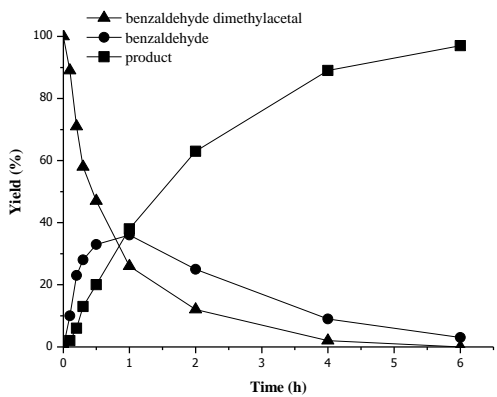

Fig.8 - Catalytic activity of the bifunctional DMAN- $\mathrm{SO}_{3} \mathrm{H} / \mathrm{SiO}_{2}-5-5$ 85 hybrid in the one-pot acetal hydrolysis-Knoevenagel condensation of malononitrile.

Table 6 - One-pot acetal hydrolysis- Knoevenagel condensation cascade reactions using malononitrile ( $3 \mathrm{a}) .6 \mathrm{~h}$ reaction time.

90

\begin{tabular}{|c|c|c|c|c|c|c|}
\hline entry & Catalysts & $\begin{array}{c}\text { Conv. } \\
\text { of } 1 \\
(\%)\end{array}$ & $\begin{array}{l}\text { Yield } \\
\text { of } \mathbf{2} \\
(\%)\end{array}$ & $\begin{array}{l}\text { Yield } \\
\text { of } \mathbf{4 a} \\
(\%)\end{array}$ & $\begin{array}{l}\mathrm{TOF}^{\mathrm{b}} \\
\left(\mathrm{min}^{-1}\right)\end{array}$ & $\begin{array}{c}\mathrm{r}_{0} \\
\left(\mathrm{~min}^{-1}\right)\end{array}$ \\
\hline 1 & DMAN-SO ${ }_{3} \mathrm{H} / \mathrm{SiO}_{2}-5-5$ & 100 & 3 & 97 & 63 & 0.63 \\
\hline 2 & DMAN-SO ${ }_{3} \mathrm{H} / \mathrm{OMS}-5-5$ & 100 & 2 & 98 & 66 & 0.68 \\
\hline 3 & grDMAN-SO ${ }_{3} \mathrm{H} / \mathrm{SiO}_{2}-5$ & 97 & 2 & 95 & 56 & 0.56 \\
\hline 4 & grDMAN-SO 3 H/OMS-5 & 99 & 3 & 96 & 58 & 0.59 \\
\hline 5 & none $^{\mathrm{a}}$ & 5 & 2 & 3 & - & - \\
\hline
\end{tabular}

acascade reaction without the heterogeneous catalyst: benzaldehyde dimethylacetal $(5.45 \mathrm{mmol})$, malononitrile $(5.24 \mathrm{mmol})$ and $\mathrm{H}_{2} \mathrm{O}(30 \mu \mathrm{l})$ at $355 \mathrm{~K}$. ${ }^{\mathrm{b}} \mathrm{TOF}$ calculated at $60 \mathrm{~min}$.

95 When ethyl cyanoacetate (3b) was used as methylene compound instead of malononitrile in the cascade reaction, the non-ordered DMAN-SO 3 H/SiO $2-5-5$ reaches $98 \%$ yields of the final product (4b) with $100 \%$ selectivity (Table 7 , entry 1) after $7 \mathrm{~h}$, whilst $86 \%$ yield was obtained at the same reaction time using 100 ordered DMAN-SO 3 H/OMS-5-5 as catalysts (Table 7, entry 2). Lower yields of the final product were observed when grafted DMAN hybrids are used as catalysts (Table 7, entries 3 and 4).

Interestingly, it can be noted that if water is not added to the cascade reaction (Table 7, entries 5 and 6) and the catalysts is not 105 outgassed at $100^{\circ} \mathrm{C}$ before the catalytic test, DMAN-SO ${ }_{3} \mathrm{H} / \mathrm{SiO}_{2}$ 5-5 hybrid shows superior catalytic activity respect to the ordered DMAN-SO ${ }_{3} \mathrm{H} / \mathrm{OMS}-5-5$ used in the same reaction conditions. In this condition, DMAN-SO $\mathrm{S}_{3} \mathrm{H} / \mathrm{SiO}_{2}-5-5$ hybrid catalyst can take advantage of the water absorbed in the mesopores due to its 110 higher hydrophilic character respect to the ordered bifunctional give the benzyilidene malononitrile (4a) as final product. The results showed that the tandem reaction was successfully
In Fig. 8, the catalytic activity in the cascade reaction, using malononitrile as methylene compound, of the bifunctional nonordered DMAN-SO ${ }_{3} \mathrm{H} / \mathrm{SiO}_{2}-5-5$ hybrid catalyst is reported. It is 55 possible to observe the conversion of benzaldehyde dimethylacetal (1) into benzaldehyde (2) that reacts through the consecutive Knoevenagel condensation with malononitrile (3a) to 
OMS, as evidenced by TGA (Fig. 3A). Finally, when only acid $\mathrm{SO}_{3} \mathrm{H} / \mathrm{OMS}-5$ or $\mathrm{SO}_{3} \mathrm{H} / \mathrm{SiO}_{2}-5$ are used as catalysts, in the absence of any base groups, benzaldehyde is the sole product (Table 7, entry 7). Reciprocally, when only base groups are 5 present in the hybrid catalysts $\left(\mathrm{DMAN} / \mathrm{SiO}_{2}-5\right)$, tandem reaction is not effective because the initial acid-catalyzed acetal hydrolysis is practically not carried out (Table 7, entry 8). Moreover, a physical mixture of acid $\mathrm{SO}_{3} \mathrm{H} / \mathrm{SiO}_{2}-5$ and base DMAN/SiO${ }_{2}-5$ was also tested in the tandem reaction and the result evidences 10 that only 5\% yield of the final product was achieved (entry 9), probably due to the chemical interaction and neutralization established between acid and base groups located in independent solids together with the inhomogeneous distribution of active sites exhibited in the catalyst mixture. So, these results 15 demonstrate that each catalyst (acid and base) on its own is unable to promote the one-pot cascade reaction, clearly indicating a cooperative behavior of the bifunctionalized hybrid catalysts when active sites cohabite in the same framework, such as occurs in enzymatic systems.

20

Table 7 - One-pot acetal hydrolysis- Knoevenagel condensation cascade reactions using ethyl cyanoacetate (3b).

\begin{tabular}{|c|c|c|c|c|c|c|}
\hline entry & Catalysts & $\mathrm{t}(\mathrm{h})$ & $\begin{array}{c}\text { Conv. } \\
\text { of } 1 \\
(\%)\end{array}$ & $\begin{array}{l}\text { Yield } \\
\text { of } 2 \\
(\%)\end{array}$ & $\begin{array}{c}\text { Yield } \\
\text { of } \mathbf{4 b} \\
(\%)\end{array}$ & $\begin{array}{l}\mathrm{TOF}^{\mathrm{b}} \\
\left(\mathrm{min}^{-1}\right)\end{array}$ \\
\hline \multirow[t]{2}{*}{1} & DMAN-SO ${ }_{3} \mathrm{H} / \mathrm{SiO}_{2}-5-5$ & 7 & 100 & 2 & 98 & 7.3 \\
\hline & & 10 & 100 & 0 & 100 & \\
\hline \multirow[t]{2}{*}{2} & DMAN-SO ${ }_{3} \mathrm{H} / \mathrm{OMS}-5-5$ & 7 & 100 & 14 & 86 & 6.1 \\
\hline & & 10 & 100 & 5 & 95 & \\
\hline \multirow[t]{2}{*}{3} & grDMAN-SO ${ }_{3} \mathrm{H} / \mathrm{SiO}_{2}-5$ & 7 & 90 & 21 & 79 & 2.0 \\
\hline & & 10 & 93 & 15 & 85 & \\
\hline \multirow[t]{2}{*}{4} & grDMAN-SO ${ }_{3} \mathrm{H} / \mathrm{OMS}-5$ & 7 & 95 & 19 & 81 & 2.4 \\
\hline & & 10 & 98 & 9 & 91 & \\
\hline \multirow[t]{2}{*}{5} & DMAN-SO ${ }_{3} \mathrm{H} / \mathrm{SiO}_{2}-5-5^{\mathrm{a}}$ & 7 & 100 & 5 & 96 & 6.6 \\
\hline & & 10 & 100 & 2 & 98 & \\
\hline \multirow[t]{2}{*}{6} & DMAN-SO ${ }_{3} \mathrm{H} / \mathrm{OMS}-5-5^{\mathrm{a}}$ & 7 & 100 & 76 & 24 & 1.1 \\
\hline & & 10 & 100 & 62 & 38 & \\
\hline 7 & $\begin{array}{l}\mathrm{SO}_{3} \mathrm{H} / \mathrm{PMO}-5 \text { or } \\
\mathrm{SO}_{3} \mathrm{H} / \mathrm{SiO}_{2}-5\end{array}$ & 24 & 100 & 100 & 0 & - \\
\hline 8 & DMAN/SiO ${ }_{2}-5$ & 24 & 7 & 2 & 5 & - \\
\hline 9 & $\mathrm{SO}_{3} \mathrm{H} / \mathrm{SiO}_{2}-5+$ & 24 & 100 & 95 & 5 & - \\
\hline 10 & $\begin{array}{l}\text { DMAN/S1O } 2-5 \\
\text { none }^{\mathrm{b}}\end{array}$ & 24 & 0 & trace & trace & - \\
\hline
\end{tabular}

acascade reaction without the addition of water and without outgassing the 25 hybrid catalysts at $100^{\circ} \mathrm{C}$ before the catalytic test.

${ }^{b}$ cascade reaction without the heterogeneous catalyst: benzaldehyde dimethylacetal $(5.45 \mathrm{mmol})$, ethyl cyanoacetate $(5.24 \mathrm{mmol})$ and $\mathrm{H}_{2} \mathrm{O}(30$ $\mu 1)$ at $355 \mathrm{~K}$

${ }^{\mathrm{c}} \mathrm{TOF}$ calculate at $90 \mathrm{~min}$.

30

When a more demanding reactant, such as diethylmalonate (scheme 4, 3c) was used as methylene compound in the second step Knoevenagel condensation, the bifunctionalized hybrids behave differently and the catalytic activity strictly depends on 35 the synthesis procedure adopted in the generation of the hybrid catalysts, as was also evidenced when ECA was used. In particular, non-ordered bifunctional DMAN-SO ${ }_{3} \mathrm{H} / \mathrm{SiO}_{2}-5-5$ shows higher yields at different reaction time with $100 \%$ selectivity (Table 8 , entry 1 ) respect to ordered DMAN${ }_{40} \mathrm{SO}_{3} \mathrm{H} / \mathrm{OMS}-5-5$ (Table 8 , entry 2 ) and in the case of the graftedDMAN bifunctional hybrid catalysts lower yields are obtained (Table 8, entries 3 and 4).
Table 8 - One-pot acetal hydrolysis- Knoevenagel condensation cascade 45 reactions using diethylmalonate $(3 \mathrm{c})$.

\begin{tabular}{|c|c|c|c|c|c|c|}
\hline$\overline{\text { entry }}$ & Catalysts & $t(h)$ & $\begin{array}{c}\text { Conv. } \\
\text { of } \mathbf{1} \\
(\%)\end{array}$ & $\begin{array}{l}\text { Yield } \\
\text { of } 2 \\
(\%) \\
\end{array}$ & $\begin{array}{c}\text { Yield } \\
\text { of } \mathbf{4 c} \\
(\%)\end{array}$ & $\begin{array}{l}\mathrm{TOF}^{\mathrm{b}} \\
\left(\mathrm{min}^{-1}\right)\end{array}$ \\
\hline \multirow[t]{3}{*}{1} & DMAN-SO ${ }_{3} \mathrm{H} / \mathrm{SiO}_{2}-5-5$ & 10 & 100 & 32 & 68 & 0.86 \\
\hline & & 15 & 100 & 25 & 75 & \\
\hline & & 24 & 100 & 4 & 96 & \\
\hline \multirow[t]{3}{*}{2} & DMAN-SO ${ }_{3} \mathrm{H} / \mathrm{OMS}-5-5$ & 10 & 100 & 56 & 44 & 0.41 \\
\hline & & 15 & 100 & 38 & 62 & \\
\hline & & 24 & 100 & 19 & 81 & \\
\hline \multirow[t]{3}{*}{3} & grDMAN-SO $3 \mathrm{H} / \mathrm{SiO}_{2}-5$ & 10 & 100 & 87 & 13 & 0.11 \\
\hline & & 15 & 100 & 80 & 20 & \\
\hline & & 24 & 100 & 18 & 82 & \\
\hline \multirow[t]{3}{*}{4} & grDMAN-SO ${ }_{3} \mathrm{H} / \mathrm{OMS}-5$ & 10 & 100 & 86 & 14 & 0.14 \\
\hline & & 15 & 100 & 82 & 18 & \\
\hline & & 24 & 100 & 34 & 66 & \\
\hline
\end{tabular}

${ }^{\mathrm{a}} \mathrm{TOF}$ calculate at $420 \mathrm{~min}$

4.2 One pot-deacetalization-nitroaldol (Henry) reaction: ${ }_{50}$ Nitroalkenes constitute valuable precursors to a wide variety of target molecules. Firstly, they were of interest because of their biological activity such as antibacterial, rodent-repelling and antitumor characteristics. ${ }^{66,67}$ Moreover, nitroalkenes can be easily transformed into a variety of different functionalities 55 (nitroalkanes, hydroxylamines, amines, ketones, oximes). They also react with a variety of nucleophiles, and constitute powerful dienophiles to Diels-Alder reactions. The classic route to produce nitroalkenes is the base-catalyzed aldol condensation of nitroalkanes also named nitroaldol or Henry ${ }^{68}$ reaction and 60 provides $\beta$-nitroalcohols which, upon dehydration, afford nitroalkenes. Different base catalysts have been used which influence the nature of the products obtained; among them, organic bases such as primary amines and ammonium acetate have been successfully used. Here we tested the catalytic activity 65 of the synthesized bifunctional hybrids in the one-pot deacetalization-nitroaldol reaction (scheme 5). In this case, in the second step, benzaldehyde (2) reacts with nitromethane (3) giving the 2-nitrovinyl benzene (4) as final product. Similarly to the reaction that involved in the second step a Konevenagel 70 condensation, the bifunctional non-ordered DMAN-SO ${ }_{3} \mathrm{H} / \mathrm{SiO}_{2}-$ 5-5 hybrid catalyst (Table 9, entry 1) shows better catalytic conversions towards the final product (4) respect to the other hybrid materials. In particular, grafted-DMAN hybrid materials showed poor activities (Table 9, entries 3 and 4).

75

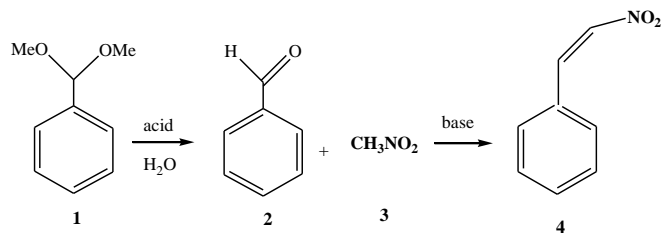

Scheme 5 - One-pot acetal hydrolysis-nitroaldol (Henry) cascade reaction. 
Table 9 - One-pot acetal hydrolysis-nitroaldol cascade reaction.

\begin{tabular}{|c|c|c|c|c|c|c|}
\hline entry & Catalysts & $\mathrm{t}(\mathrm{h})$ & $\begin{array}{c}\text { Conv. } \\
\text { of } \mathbf{1} \\
(\%)\end{array}$ & $\begin{array}{c}\text { Yield } \\
\text { of } 2 \\
(\%)\end{array}$ & $\begin{array}{c}\text { Yield } \\
\text { of } \mathbf{4} \\
(\%)\end{array}$ & $\begin{array}{c}\mathrm{TOF}^{\mathrm{b}} \\
\left(\mathrm{min}^{-1}\right)\end{array}$ \\
\hline \multirow[t]{2}{*}{$\overline{1}$} & DMAN-SO ${ }_{3} \mathrm{H} / \mathrm{SiO}_{2}-5-5$ & 15 & 100 & 40 & 60 & 0.33 \\
\hline & & 24 & 100 & 8 & 92 & \\
\hline \multirow[t]{2}{*}{2} & DMAN-SO ${ }_{3} \mathrm{H} / \mathrm{OMS}-5-5$ & 15 & 100 & 53 & 47 & 0.15 \\
\hline & & 24 & 100 & 14 & 86 & \\
\hline \multirow[t]{2}{*}{3} & grDMAN-SO ${ }_{3} \mathrm{H} / \mathrm{SiO}_{2}-5$ & 15 & 100 & 85 & 15 & 0.02 \\
\hline & & 24 & 100 & 72 & 28 & \\
\hline \multirow[t]{2}{*}{4} & grDMAN-SO ${ }_{3} \mathrm{H} / \mathrm{OMS}-5$ & 15 & 100 & 78 & 22 & 0.08 \\
\hline & & 24 & 100 & 69 & 31 & \\
\hline 5 & none $^{\mathrm{a}}$ & 24 & 5 & trace & trace & - \\
\hline
\end{tabular}

5 The catalytic performances of the different bifunctional hybrids in the one-pot cascade reactions have evidenced a superior activity of the non-ordered acid-base hybrid mesoporous materials with respect to the other hybrids especially when, in the second step, a more demanding methylene compound, such as 10 DEM or nitromethane are involved. This superior activity could be inferred by the higher structural flexibility of the non-ordered silica network and by the higher amount of silanol groups that can perform a cooperative electrophilic activation, although its specific surface area is lower than the exhibited by the ordered${ }_{15}$ OMS materials. ${ }^{2,69,70}$ The beneficial effect of silanol groups is clearly confirmed through silylation of hybrid samples with nonordered silica structure, where the surface $\mathrm{Si}-\mathrm{OH}$ groups are deactivated by pending silyl-methyl moieties on the walls. ${ }^{71}$ In fact, the silylated solids have shown reduced catalytic activities 20 with final yields to desired product (4) lower than $15 \%$ after $24 \mathrm{~h}$ of reaction.

In the case of grafted-hybrids, the catalytic activity observed is lower with respect to the one-pot hybrid materials. It is, in fact, difficult to achieve a homogeneous distribution of the organic 25 groups when post synthetic grafting is used and moreover, if the grafting reagents react preferentially at the pore openings during the initial stages of the synthesis process, the diffusion of further molecules into the centre of the pores can be hampered. ${ }^{69,}{ }^{72}$ In addition, also the densely packed organic base moieties that 30 greatly reduce the percentage of silanols (as evidence by TGA analysis) can affect negatively the catalytic activity of these hybrids. The probability of such aggregation effects is reduced in the one-pot synthesized hybrids and thus hybrid catalysts with spatially well isolated acid and base groups can be achieved.

35

4.3 Catalytic reuses: Catalyst deactivation and reusability was studied by recycling the used hybrid catalysts after each run, being consecutively washed with $\mathrm{CH}_{2} \mathrm{Cl}_{2}$. The yields of the recycled catalysts in the one-pot acetal hydrolysis-Knoevenagel 40 condensation cascade reaction with ethyl cyanoacetate after $10 \mathrm{~h}$ of reaction are presented in Fig. 9. It can be observed that the one-pot hybrid catalysts can be recycled with only slight loss in activity during three consecutive catalytic cycles. More marked decrease in the activity after the $3^{\text {rd }}$ run is observed when grafted 45 hybrids were used as catalysts. No leaching of the organic functionalities was observed by performing elemental analysis on the used one-pot hybrids (Table 1 in SI), whilst a more evident loss in the $\mathrm{N}$ content is observed for the grafted-DMAN hybrids.
50

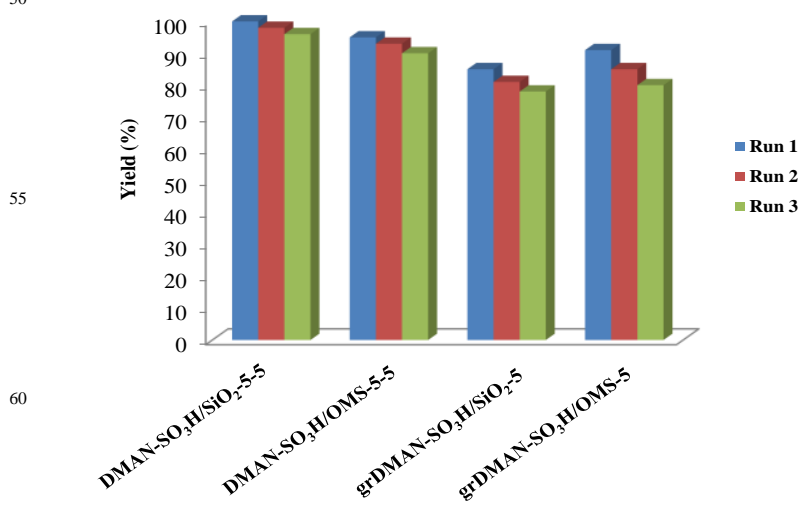

Fig. 9 - Recycling tests of one-pot acetal hydrolysis-Knoevenagel 65 condensation cascade reactions using ethyl cyanoacetate. The yield (\%) is reported after $10 \mathrm{~h}$ of reaction.

\section{Conclusions}

${ }_{70}$ Bifunctional acid-base mesoporous hybrid catalysts containing simultaneously strong base and acid groups have been successfully synthesized and used in consecutive catalytic transformations. Different synthetic procedures to generate ordered and non-ordered bifunctional hybrids have been used: 75 one-pot co-condensation processes $\left(\mathrm{NH}_{4} \mathrm{~F}\right.$ sol-gel or micellar one-pot route) or post-synthetic grafting of the organic functionalities.

1,8-bis(dimethylamino)naphthalene (DMAN), a proton sponge with high $\mathrm{pK}_{\mathrm{a}}$, was used as organic functional builder 80 base and 3-mercaptopropyltriethoxysilane (MPTES) as pending precursor of sulfonic acids which were obtained by oxidation of thiol groups using $\mathrm{H}_{2} \mathrm{O}_{2}$ without protection of the DMAN base molecules. The characterisation of the hybrids has revealed that the organic base and the sulfonic acids are preserved inside the 85 mesoporous silica network providing strong base and acid properties to the hybrid materials. These hybrid catalysts were tested in the one-pot-two step processes that involved an acidcatalyzed acetal hydrolysis followed by a base-catalyzed Knoevenagel or nitroaldol (Henry) reactions. In particular, non90 ordered hybrid, prepared by $\mathrm{NH}_{4} \mathrm{~F}$ catalyzed one-pot route, has shown higher catalytic activity with respect to the other hybrids especially when, in the second step, a more demanding methylene compound, such as DEM or nitrometane are involved. This superior activity could be inferred by the higher structural 95 flexibility of the non-ordered silica network and by the higher amount of silanol groups that can perform a cooperative electrophilic activation. The successful cohabitation of acid and base groups inside the channels of mesoporous non-ordered organosilica materials and the good catalytic performances 100 observed by this hybrid catalyst, have evidenced that a facile synthetic route (a fluoride-catalysed sol-gel process, at neutral $\mathrm{pH}$ and low temperatures, without the use of SDAs) can be followed to produce highly active bifunctional hybrid catalysts and that this synthetic strategy can open the way to the rational design of 105 novel types of multifunctional hybrid materials. 


\section{Acknowledgments}

The authors thank financial support to Spanish Government by Consolider-Ingenio MULTICAT CSD2009-00050, MAT20115 29020-C02-01 and Severo Ochoa Excellence Program SEV2012-0267. EG thanks Marie Curie Fellowship (FP7-PEOPLE2009-IEF) for financial support.

\section{Notes and references}

${ }^{a}$ Instituto de Tecnología Química (UPV-CSIC) Universidad ${ }_{10}$ Politécnica de Valencia. Consejo Superior de Investigaciones Científicas. Avenida de los Naranjos s/n., 46022 Valencia. Spain. E-mail:udiaz@itq.upv.es

${ }^{b}$ Dipartimento di Scienze e Innovazione Tecnologica, Centro Interdisciplinare Nano-SiSTeMI, Università del Piemonte 15 Orientale, Via T. Michel 11, I-15100, Alessandria, Italy

E-mail: enrica.gianotti@unipmn.it

$\dagger$ Electronic Supplementary Information (ESI) available: Figure 1 corresponds to NMR characterisation of silyl derived DMAN and ${ }_{20}$ Table 1 shows the organic content of the fresh mesoporous bifunctional hybrids and after the $3^{\text {th }}$ catalytic run estimated by elemental analysis. See DOI: 10.1039/b000000x/

1 S. Shylesh and W.R. Thiel, ChemCatChem, 2011, 3, 278-287.

252 K.K. Sharma, R.P. Buckley and T. Asefa, Langmuir, 2008, 24, 14306 -14320 .

3 J.D. Bass, A. Solovyov, A.J. Pascall and A. Katz, J. Am. Chem. Soc., 2006, 128, 3737-374.

4 J.D. Bass and A. Katz, Chem. Mater., 2006, 18, 1611-1620.

305 D. Coutinho, S. Madhugiri and K.J. Balkus Jr., J. Porous Mater., 2004, 11, 239-254.

6 S. Huh, H.-T. Chen, J.W. Wiench, M. Pruski and V.S.-Y. Lin, J. Am. Chem. Soc., 2004, 126, 1010-1011.

7 S. Huh, H.-T. Chen, J.W. Wiench, M. Pruski and V.S.-Y. Lin, Angew.

35 Chem. Int. Ed., 2005, 44, 1826-1830.

8 N.R.Shiju, A.H.Alberts, S.Khalid, D.R. Brown and G. Rothenberg, Angew. Chem. Int. Ed., 2011, 59, 9615-9616.

9 K. Motokura, M. Tomita, M. Tada and Y. Iwasawa, Chem. Eur. J., 2008, 14,4017-4027.

4010 Y. Huang, S. Xu and V. S.-Y. Lin, Angew. Chem. Int. Ed., 2011, 50, 661-664.

11 S. Shylesh, A. Wagner, A. Seifert, S. Ernst and W.R. Thiel, Chem. Eur. J., 2009, 15, 7052-7062.

12 M. Jaroniec, Nature, 2006, 442, 638-640.

4513 J. Alauzun, A. Mehdi, C. Reye' and R.J.P. Corriu, J. Am. Chem. Soc., 2006, 128, 8718-8719.

14 S. Shylesh, A. Wagner, A. Seifert, S. Ernst and W.R. Thiel, Angew. Chem. Int. Ed., 2010, 49, 184-187.

15 R.K. Zeidan, S.-J. Hwang and M.E. Davis, Angew. Chem. Int. Ed., 2006, 45, 6332-6335.

16 Y. Huang, B. G. Trewyn, H.-T. Chen and V. S.-Y. Lin, New J. Chem., 2008, 32, 1311-1313.

17 H. Yang, G. Li, Z. Ma, J. Chao and Z. Guo, J. Catal., 2010, 276, 123 133.

5518 H. Zhao, N. Yu, J. Wang, D. Zhuang, Y. Ding, R. Tan and D. Yiu, Microp. Mesop. Mater., 2009, 122, 240-246.

19 T.P. Nguyen, P. Hesemann, P. Gaveau and J.J.E. Moreau, J. Mater. Chem., 2009, 19, 4164-4171.

20 M. Trilla, R. Pleixats, M.W.C. Man and C. Bied, Green Chem., 2009, $60 \quad \mathbf{1 1}, 1815-1820$

21 Y. Xie, K.K. Sharma, A. Anan, G. Wang, A. V. Biradar and T. Asefa, J. Catal., 2009, 265, 131-140.

22 K. Motokura, M. Tada and Y. Iwasawa, J. Am. Chem. Soc., 2007, 129, 9540-9541.

6523 A. Corma, U. Diaz, T. Garcia, G. Sastre and A. Velty, J. Am. Chem. Soc., 2010, 132, 15011-15021.

24 C. Sánchez, B. Julián, P. Belleville and M. Popall, J. Mater. Chem., 2005, 15, 3559-3592.

25 C. Sánchez and F. Ribot, New J. Chem., 1994, 18, 1007-1047.
7026 C. Sánchez, L. Rozes, F. Ribot, C. Laberty-Robert, D. Grosso, C. Sassoye, C. Boissiere and L. Nicole, C.R. Chim., 2010, 13, 3-39.

27 D.M. Ford, E.E. Simanek and D.F. Shantz, Nanotechnology 2005,16, 458-475.

28 E.J.A. Pope and J.D. Mackenzie, J. Non-Cryst. Solids, 1986, 87, 185198

29 R. Winter, J.B. Chan, R. Frattini and J. Jonas, J. Non-Cryst. Solids, 1988, 105, 214-222.

30 E. Reale, A. Leyva, A. Corma, C. Martinez, H. Garcia and F. Rey, J. Mater. Chem., 2005, 15, 1742-1754.

8031 U. Diaz, T. Garcia, A. Velty and A. Corma, J. Mater. Chem., 2009, 19, 5970-5979.

32 A. Mehdi, C. Reye, S. Branders, R. Guilard and R.J.P. Corriu, New J. Chem., 2005, 29, 965-968.

33 A. Katz and M.E. Davis, Nature, 2000, 403, 286-289.

8534 E. Gianotti, U. Diaz, S. Coluccia and A. Corma, Phys. Chem. Chem. Phys., 2011, 13, 11702-11709.

35 A. Corma, S. Iborra, I. Rodriguez and F. Sanchez, J. Catal., 2002, 211, 208-215.

36 R. Mokaya and W. Jones, J. Mater. Chem., 1998, 8, 2819-2826.

9037 S. J. Gregg and K. S. W. Sing, Adsorption, Surface Area and Porosity, Academic Press, London, 1982.

38 K. S. W. Sing, D. H. Everett, R. A. W. Haul, L. Moscou, R. A. Pierotti, J. Rouquerol and T. Siemieniewska, Pure Appl. Chem., 1985, 57, 603-619.

9539 E. P. Barrett, L. G. Joyner and P. P. Halenda, J. Am. Chem. Soc., 1951, 73, 373- 380 .

40 P. T. Tanev and T. J. Pinnavaia, Science, 1995, 267, 865-867.

41 D. Margolese, J.A. Melero, S.C. Christiansen, B.F. Chmelka and G.D. Stucky, Chem. Mater., 2000, 12, 2448-2459.

10042 S. Shylesh, S. Sharma, S.P. Mirajkar and A.P. Singh, J. Molec. Catal. A: Chemical, 2004, 212, 219-228.

43 K. Woźniak, J. Mol. Struct., 1996, 374, 317-326.

44 A.F. Pozharskii, Russian Chem. Rev., 1998, 67, 1-24.

45 Y. Seo, S. Park and D.H. Park, J. Solid State Chem., 2006, 179, $1285-1288$.

46 W.M. Van Rhijn, D.E. De Vos, B.F. Sels, W.D. Bossaert and P.A Jacobs, Chem. Commun., 1998, 317-318.

47 J.A. Melero, R. van Grieken and G. Morales, Chem. Rev., 2006, 106, 3790-3812.

11048 K. Kawahara, Y. Hagiwara, A. Shimojima and K. Kuroda, J. Mater Chem., 2008, 18, 3193-3195.

49 L.J. Bellamy, Advances in Infrared Group Frequencies, Chapman and Hall, London, 1968

50 I. Rodriguez, S. Iborra, F. Rey and A. Corma, Appl. Catal. A General, 2000, 194-195, 241-252.

51 M.J. Climent, A. Corma, S. Iborra, K. Epping and A. Velty, J. Catal., 2004, 225, 316-326

52 F.A. Luzzio, Tetrahedron, 2001, 57, 915-945

53 G. Sartori, F. Bigi, R. Maggi, R. Sartorio, D.J.Macquarrie, M. 120 Leonardo, L. Storaro, S. Coluccia and G. Martra, J. Catal., 2004, 222, 410-418

54 M.J. Climent, A. Corma and S. Iborra, Chem. Rev., 2011, 111, 1072 1133.

55 T. Hara, S. Kanai, K. Mori, T. Mizugaki, K. Ebitani, J. Jitsukawa and K. Kaneda, J. Org. Chem., 2006, 71, 7455-7462.

56 S.L. Poe, M. Kobaslija and D.T. McQuade, J. Am. Chem. Soc., 2006, 128, 15586-15587.

57 K. Motura, M. Tada and Y. Iwasawa, Angew. Chem. Int. Ed., 2008,47, 9230-9235.

13058 G. Jones, Organic Reactions; Wiley: New York, 1967, 15, 204-599.

59 L.F. Tietze and U. Beifuss, U., Comprehensive Organic Synthesis; Pergamon Press: Oxford, U.K., 1991, 2, 341-394.

60 W. Lubisch, E. Beckenbach, S. Bopp, H.-P. Hofmann, A. Kartal, C. Kaestel, T. Lindner, M. Metz-Garrecht, J. Reeb, F. Regner, M. Vierling and A. Moeller, J.Med. Chem., 2003, 46, 2404-2412.

61 N. Vlok, S.F. Malan, N. Castagnoli, J.J. Bergh and J.P. Petzer Bioorg. Med. Chem., 2006, 14, 3512-3521.

62 T. Shiraishi, M.K. Owada, M. Tatsuki,Y. Yamashita and T. Kaunaga, Cancer Res., 1989, 49, 2374-2378.

14063 C. Selvam, S.M. Jachak, R. Thilagavathi and A.K. Chakraborti, Bioorg. Med. Chem. Lett., 2005, 15, 1793-1798. 
64 K. Nakayama, Y. Ishida, M. Ohtsuka, H. Kawato, K. Yoshida, Y. Yokomizo, S. Hosono, T. Ohta, K. Hoshino, H. Ishida and K.Yoshida, Bioorg. Med. Chem. Lett., 2003, 13, 4201-4204.

65 U. Diaz, T. Garcia, A. Velty and A. Corma, Chem. Eur. J., 2012, 18(28), 8659-8672.

66 O. Schales and H. A. Graefe, J. Am. Chem. Soc., 1952, 74, 44864490.

67 K. Zee-Cheng and C. Cheng, J. Med. Chem., 1969, 12, 157-161.

68 L. Henry, Compt. Rend., 1895, 120, 1265-1268.

1069 S.L. Hurby and B.H. Shanks, J. Catal., 2009, 263, 181-188.

70 E. Poli, E. Merino, U. Diaz, D. Brunel and A. Corma, J. Phys. Chem $C, 2011,115,7573-7585$.

71 A. Corma, M. Domine, J.A. Gaona, J.L. Jorda, M.T. Navarro, F. Rey, J. Pérez-Pariente, J. Tsuji, B. McCulloch and L.T. Nemeth,

15 Chem. Commun., 1998, 20, 2211-2212.

72 F. Hofmann and M. Froba, Chem. Soc. Rev., 2011, 40, 608-662. 